Volume 1, Nomor 2, Desember 2018

\title{
ANALISIS KEAMANAN SIKAPEG IVET BERBASIS ISO 27001:2013
}

\author{
Reni Veliyanti ${ }^{1)}$, Marwata ${ }^{2)}$, Irwan Sembiring ${ }^{3)}$ \\ ${ }^{1,2,3}$ Teknologi Informasi Universitas Kristen Satya Wacana

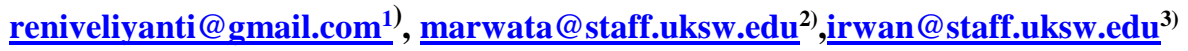

Diterima: Desember 2018. Disetujui: Desember 2018. Dipublikasikan: Desember 2018

\begin{abstract}
ABSTRAK
Keamanan data sangat penting, sebab dapat memastikan kontinuitas pengelolaan, mengurangi risiko, dan menjadi peluang suatu lembaga untuk berkembang. Semakin banyak informasi yang dikelola dan dishare semakin besar pula risiko terjadinya kerusakan, kehilangan atau tereksposnya data ke pihak eksternal yang tidak bertanggung jawab. Tujuan penelitian untuk mendeskripsikan bentuk-bentuk ancaman keamanan dan langkah penanganan ancaman keamanan SIKAPEG. Penelitian termasuk penelitian mixed method yang difokuskan pada aktivitas sistem keamanan informasi terkait dengan kehadiran pegawai di IVET. Simpulan penelitian bahwa sistem keamanan SIKAPEG di IVET belum memenuhi standar ISO 27001:2013, beberapa indikator telah dilaksanakan namun ada yang kurang baik. Terjadinya ancaman termasuk pada kriteria mungkin terjadi, hal ini dilihat dari indikatornya kemungkinan terjadi ancaman rentangan antara $10-50 \%$ dalam waktu 1(satu) tahun. Sedangkan jika dikaitkan dengan skala Likelihood termasuk kriteria ringan, yaitu gangguan terhadap aplikasi/jaringan. Kelemahannya terletak pada tidak adanya tanggung jawab prosedur manajemen keamanan informasi, tidak ada bukti pelaporan hambatan keamanan informasi yang terdokumen, sehingga tidak bisa digunakan sebagai evaluasi mendatang, dan kurangnya kesadaran pegawai dalam melakukan presensi sidik jari, kurangnya empati dan kesadaran secara bersama menjaga dan merawat serta memelihara hardware pendukung. Pemeliharaan dan perawatan oleh teknisi sudah baik, namun belum dilaksanakan secara menyeluruh sehingga ada beberapa hardware yang mudah rusak karena titik lemah pada aplikasi, hardware, SDM merupakan potensi sumber ancaman keamanan yang berkembang menjadi gangguan pada SIKAPEG. Solusi sebagai rekomendasi, sebaiknya dilakukan kontrol secara periodik dan berkala, perawatan dan pemeliharaan secara menyeluruh, terdokumentasi saat dilakukan kontrol serta penetapan kebijakan secara tegas.
\end{abstract}

Kata kunci:keamanan sistem informasi, ISO 27001:2013.

\begin{abstract}
Data security is very important, because it can ensure continuity of management, reduce risk, and become an opportunity for an institution to develop. The more information that is managed and shared, the greater the risk of data damage, loss or exposure to irresponsible external parties. The research objective is to describe the forms of security threats and steps to deal with SIKAPEG security threats. Research includes mixed method research which is focused on information security system activities related to the presence of employees at IVET. The conclusion of the study is that the SIKAPEG security system at IVET has not met the ISO 27001: 2013 standard, some indicators have been implemented but some have not been good. The occurrence of threats included in the criteria may occur which is the threat possibility indicator ranges from $10-50 \%$ within 1 (one) year. If it is associated with the Likelihood scale, it is included in the criteria of minor interference, which is the interference in the application / network. The weaknesses lie in the absence of information security management procedure responsibilities and no evidence of documented information security barriers, so that it cannot be used as an upcoming evaluation, and the lack of awareness of employees in fingerprint attendance, lack of empathy and awareness to maintain and care for the supporting hardware. Maintenance by technicians are good, but have not been carried out thoroughly so that there is some hardware that is easily damaged because of the weak points in applications, hardware, and human resources are potential sources of security threats that develop into disruptions in SIKAPEG. As solutions, a periodic control, a thorough maintenance, a documented control, and a policy determination are required.
\end{abstract}

Keywords: information system security, ISO 27001:2013. 


\section{PENDAHULUAN}

Semakin banyak informasi yang dimanfaatkan oleh publik, maka semakin memiliki peluang untuk menerima risiko. Baik kerusakan, hilangnya data, dan terbacanya data oleh pihak luar yang tidak bertanggung jawab. Oleh karenanya standar layanan dan keamanan menjadi salah satu solusi, namun pada kenyataannya dalam penerapan standar baku masih sulit dilakukan pada sebuah organisasi. Hal itu dimungkinkan terjadi karena ruang lingkup atau fokus sebuah standar dirasa kurang luas cakupannya untuk memenuhi seluruh kebutuhan manajemen TI (Castro, 2016). Lebih lanjut dikemukakan bahwa semakin maju dan canggihnya teknologi terkini terkait dengan penggunaan TI, semakin meningkat potensi kejahatan manusai dengan kemampuan mengoperasikan TI yang canggih, orang jahat akan terus berimprovisasi dengan kemajuan yang ada. Ancaman bagi keamanan TI terjadinya efek yang muncul dari tiga kejadian, meliputi aspek: confidentiality, integrity, dan availability (CIA). Maka dari itu perlu dilakukan audit sistem informasi sebagai evaluasi sesuai fakta dan proses pengumpulan untuk menentukan sistem komputer yang digunakan dapat melindungi aset sutau organisasi atau tidak, kemampuan dalam melindungi integritas data, membantu pencapaian tujuan organisasi yang efektif, dan penggunaan sumber daya secara efisien (Santos, Marwata dan Sembiring, 2014).

Sistem pengelolaan keamanan informasi merupakan suatu rencana strategis perlu dilakukan untuk meminimalisir kelemahan dan mengurangi potensi risiko yang sedang berjalan, dengan proses mengurangi risiko serta melakukan penilaian dan juga kontrol. Pengelolaan keamanan informasi merupakan suatu yang penting untuk dipahami, diupayakan dan dicoba guna diterapkan agar informasi bisa dikelola dengan baik, agar lembaga fokus dalam pencapaian visi dan misi lembaga yang sudah ditetapkan, selain dilakukan pengembangan usaha untuk memberikan layanan prima kepada pelanggan termasuk yang dilakukan oleh IKIP Veteran Jawa Tengah Semarang (IVET).

IVET sebagai salah satu Perguruan Tinggi (PT) swasta yang dalam implementasi tata kelola TI belum dapat berjalan secara maksimal, sebab belum diketahuinya secara mendalam tingkat keamanan pada TI yang dapat dipakai untuk mendukung kemajuan dan perkembangan lembaga, di samping belum dimilikinya sistem yang mengkaitkan antara bagian struktur satu dengan bagian struktur lain. Peningkatan kedisiplinan kinerja pegawai (dosen dan tenaga administrasi) pada kehadiran, pimpinan IVET menempuh kebijakan dengan menggunakan mesin absensi sidik jari dan mesin absensi wajah yang telah terhubung secara online dengan sistem yang disebut Sistem Informasi Kehadiran Pegawai (SIKAPEG). Pimpinan dapat melihat langsung laporan kehadiran setiap hari dari SIKAPEG, bahkan setiap waktu. Namun seiring perjalanan waktu, sistem tersebut mengalami berbagai masalah dan kendala baik dari internal maupun eksternal. Kendala itu misalnya mesin tidak bisa membaca atau melakukan scan sidik jari atau wajah karena mengalami kerusakan (error) dan kerusakan pada sarana hardware pendukung seperti kerusakan komputer, sehingga kejadian itu berdampak pada perhitungan kehadiran yang berakibat pula pada insentif kehadiran yang diterima.

Penelitian tentang keamanan sistem informasi sudah dilakukan diantaranya adalah Kohar, etal. (2014), yang melakukan penelitian dengan tujuan untuk mengetahui ancamana terhadap keamanan sistem informasi kesehatan, khususnya Sistem Manajemen Rumah Sakit. Hasil penelitian diperoleh simpulan bahwa ancaman yang paling tinggi terhadap keamanan sistem informasi kesehatan adalah ancaman dari peretas.

Anggrini Kongo (2016) hasil 
penelitiannya menyarankan perlu adanya prosedur penanganan risiko pada TI yang digunakan, dimulai dari adanya persyaratan/kontrak yang jelas dengan pihak luar untuk antisipasi jika masih terjadi risiko. Hasil penelitian juga ditemukan bahwa terkait dengan software; risiko dikenakan dengan regulasi DMCA karena beberapa software yang digunakan ternyata belum berlisensi. Pada software; beberapa sistem informasi sulit diakses karena web hosting masih dipegang oleh pihak luar. Terkait dengan infrastruktur, sebenarnya memiliki peluang besar, karena FTI memiliki infrastruktur yang memenuhi spesifikasi. Risiko kerusakan karena bencana alam dan listrik mati. Pada hardware security, risiko disebabkan mematikan server secara sengaja karena lokasi server yang diketahui banyak orang. Adapun dilihat dari SDM, kurangnya kemampuan SDM dalam laboran FTIUKSW, sehingga berakibat terhambatnya pada akses data.

Darmawan (2017) dari hasil penelitiannya memberikan rekomendasi bahwa perlu peningkatan sistem keamanan FTI-UKSW karena belum maksimalnya sistem keamanan tersebut. Dikemukakan juga bahwa sistem keamanan di FTI-UKSW perlu menggunakan acuan berstandar ISO 27001:2013.

Berdasarkan penelitian relevan sebagai pendahulu terkait kajian keamanan sistem informasi dan kelemahan SDM pengoperasiannya yang belum didasarkan pada standar ISO 27001:2013, maka kelemahan tersebut dijadikan sebagai dasar peneliti untuk melakukan penelitian lanjutan, sehingga ditemukan teori baru tentang sistem keamanan informasi berstandar ISO 27001:2013.

Mengacu pada latar belakang di atas, rumusan masalah penelitian: apakah bentuk-bentuk ancaman keamanan dan langkah penanganan ancaman keamanan
SIKAPEG?. Mengacu rumusan masalah, tujuan penelitian ini adalah menganalisis dan mendeskripsikan bentuk-bentuk ancaman keamanan dan langkah penanganan ancaman keamanan SIKAPEG.

\section{TINJAUAN PUSTAKA}

Tinjauan pustaka ini membicarakan tentang keamanan sistem informasi dan ISO 27001: 2013 sebagai berikut.

\section{Keamanan Sistem Informasi}

Keamanan yang efektif perlu diperhatikan semua pihak. Pentingnya pemahaman sistem informasi adalah, sebab informasi yang valid sangat diperlukan dalam sebuah organisasi publik (Laudon \& Laudon, 2015). Dikemukakan lebih lanjut bahwa ancaman dalam sistem informasi dapat dikategorikan menjadi 7 (tujuh) macam, yaitu: (1) hardware failure: disebabkan oleh padamnya voltase listrik naik-turun, korsleting, atau disk crashes, (2) software failure: disebabkan kesalahan sistem operasi, kesalahan program update, tidak cukup, dan memadainya ujicoba program, (3) kegagalan SDM: dikarenakan sangat minimnya training bagi personel, personel yang sangat pasif atau kurang empati (sense of belonging), (4) alam, dikarenakan oleh cuaca, gas, banjir, gempa, proyektil atau letusan gunung, (5) keuangan: disebabkan oleh tuntutan hukum pihak ketiga, pailit, mogok kerja, atau hura-hura, (6) eksternal: sabotase, spionase, hura-hura, dan (7) internal: dalam bentuk kecurangan, pencurian, perbuatan jahat (memasukkan virus, atau membangun malicious software).

\section{ISO 27001:2013}

Menurut Buku Panduan Peneraan Sistem Manajemen Keamanan Informasi Berbasis Indeks Keamanan Informasi (indeks KAMI) Ver 1.0 September 2017, SNI ISO 27001:2013 telah mengadopsi format terkini dari standar sistem manajemen dengan merujuk pada standar yang dikembangkan ISO sebelumnya 
(Aprian, Rizal, \& Sobri, 2015). Lampiran A dijelaskan bagian standar yang menetapkan "sasaran kontrol" dan "kontrol" langsung diadopsi dari ISO 27001:2013. Lampiran itu menguraikan 114 kontrol dari 14 area kontrol dapat digunakan untuk pelindung informasi di berbagai organisasi. Dari 14 area kontrol ISO 27001:2013 yang digunakan pada penelitian ini 10 (sepuluh) area kontrol. Keempat area kontrol tidak diterapkan di lapangan, karena tuntutan indikator dari keempatnya belum tersedia di objek penelitian. Ke-10 area kontrol yang dimaksud: (1) A.5 Security Policies, (2) A.6 Organisation of Information Security, (3) A.7 Human Resource Security, (4) A.8 Asset Management, (5) A.9 Acces Control, (6) A.11 Physicaland Environmental Security, (7) A.12 Operations Security, (8) A.13 Communications Security, (9) A.14 System Acquisitio, Delelopmentand Maintenance, dan (10) A.16 Information Security Incident Management.

\section{METODEPENELITIAN}

Jenis penelitian yang digunakan termasuk penelitian campuran (mixed method), yaitu penggunaan data kuantitatif dan kualitatif (Tashakkori \& Teddlie, 2010). Penelitian difokuskan pada aktivitas sistem keamanan informasi terkait dengan kehadiran pegawai baik tenaga edukatif maupun adminitrasi di IVET. Sumber data diperoleh dari: (1) informan melalui wawancara, (2) dokumen, dan (3) aktivitas. Data dihimpun dari: (1) data yang dimiliki Kepala Kepegawaian, (2) data Kepala Unit TIK, (3) apresiasi tenaga edukatif dan tenaga administrasi pada kehadiran, (4) faktor pendukung dan penghambat penggunaan mesin kehadiran, serta (5) solusi yang ditawarkan terkait hambatan dalam penggunaan SIKAPEG dari hasil wawancara Kepala Unit TIK sebagai informan kunci dan Kepala Kepegawaian sebagai informan tambahan.
Analisis data digunakan metode deskriptif persentase dan model interaktif meliputi: (1) reduksi data, (2) sajian data, dan (3) penarikan simpulan/verifikasi yang disajikan dalam bentuk laporan hasil penelitian, sedangkan keabsahan data digunakan triangulasi dan memberchek. Ke10 area kontrol untuk melakukan analisis ancaman terhadap SIKAPEG di IVET digunakan kriteria Sistem Manajemen Keamanan Informasi (SMKI) seperti pada tabel berikut.

Tabel 1. Kriteria Kemungkinan Terjadi Ancaman Kemungkinan

\begin{tabular}{cl}
\multicolumn{4}{l}{ Kemungkinan } \\
\hline $\begin{array}{c}\text { 1. Hampir pasti } \\
\text { (Almostertain }\end{array}$ & $\begin{array}{l}>90 \% \text { akan terjadi dalam } \\
\text { periode waktu satu (1) tahun }\end{array}$ \\
\hline $\begin{array}{c}\text { 2. Sering } \\
\text { (likely) }\end{array}$ & $\begin{array}{l}\text { Antara 50-90\% akan terjadi } \\
\text { dalam periode waktu satu (1) } \\
\text { tahun }\end{array}$ \\
\hline $\begin{array}{l}\text { 3. Mungkin } \\
\text { (possible) }\end{array}$ & $\begin{array}{l}\text { Antara 10-50\% akan terjadi } \\
\text { tahun periode waktu satu (1) }\end{array}$ \\
\hline 4. Jarang (rare) & $<10 \%$ akan terjadi dalam \\
& periode waktu satu (1) tahun \\
\hline
\end{tabular}

Adapun kriteria dampak (impact) dari jenis kejadian atau ancaman dapat digunakan skala Likelihood sebagai berikut.

Tabel 2. Jenis Kejadian dan Skala Likelihood

\begin{tabular}{|c|c|c|c|c|}
\hline \multicolumn{5}{|c|}{ (Kemungkinan) } \\
\hline $\begin{array}{l}\text { Kate } \\
\text {-gori }\end{array}$ & $\begin{array}{c}\text { Sangat } \\
\text { Kecil }\end{array}$ & Ringan & $\begin{array}{l}\text { Mene } \\
\text {-ngah }\end{array}$ & Berat \\
\hline $\begin{array}{l}\text { Gang } \\
\text { guan } \\
\text { terha } \\
\text { dap } \\
\text { aplik } \\
\text { asi } \\
e \text { - } \\
\text { gove } \\
\text { rnme } \\
\text { nt }\end{array}$ & $\begin{array}{l}\text { Aplikasi } \\
\text { tidak } \\
\text { dapat } \\
\text { diakses } \\
<1 \text { jam di } \\
\text { luar jam } \\
\text { kerja }\end{array}$ & $\begin{array}{l}\text { Aplikasi } \\
\text { tidak } \\
\text { berfungsi } \\
>1-4 \\
\text { jam } \\
\text { selama } \\
\text { jam } \\
\text { kerja }\end{array}$ & $\begin{array}{l}\text { Aplika } \\
\text { si } \\
\text { tidak } \\
\text { berfun } \\
\text { gsi } \\
>4- \\
24 \text { jam } \\
\text { selam } \\
\text { a jam } \\
\text { kerja }\end{array}$ & $\begin{array}{l}\text { Aplikasi } \\
\text { tidak } \\
\text { berfungsi } \\
\text { lebih dari } \\
24 \quad \text { jam } \\
\text { selama jam } \\
\text { keja }\end{array}$ \\
\hline $\begin{array}{l}\text { Gang } \\
\text { guan } \\
\text { terha } \\
\text { dap } \\
\text { aplik } \\
\text { asi/ } \\
\text { jarin }\end{array}$ & $\begin{array}{l}\text { Jaringan } \\
\text { tidak } \\
\text { dapat } \\
\text { diakses } \\
<1 \text { jam di } \\
\text { luar jam } \\
\text { kerja }\end{array}$ & $\begin{array}{l}\text { Sistem } \\
\text { tidak } \\
\text { berfungsi } \\
>\quad 1-4 \\
\text { jam } \\
\text { selama } \\
\text { jam }\end{array}$ & $\begin{array}{l}\text { Sistem } \\
\text { tidak } \\
\text { berfun } \\
\text { gsi } \\
>4- \\
24 \text { jam } \\
\text { selam }\end{array}$ & $\begin{array}{l}\text { Sistem } \\
\text { tidak } \\
\text { berfungsi } \\
\text { lebih dari } \\
24 \\
\text { jam selama } \\
\text { jam keja }\end{array}$ \\
\hline
\end{tabular}




\begin{tabular}{llllll}
\hline gan & & kerja & $\begin{array}{l}\text { a jam } \\
\text { kerja }\end{array}$ & \\
\hline Kelu & Keluhan & Keluhan & Keluh & Keluhan \\
han & kecil dan & dialami & an & dimuat di \\
user & tidak & dan & dimua & mediai & \\
& Signifika & disampai & t di & lokal \& \\
& $\mathrm{n}$ & kan & media & nasional \\
& & oleh & lokal & \\
& & sejumlah & & \\
& & pengguna & & \\
\hline
\end{tabular}

Wawancara Informan digunakan Internal Control Questionnaires (ICQs). ICQs didesain menggunakan skala Guttman sehingga diperoleh jawaban tegas "Ya" dan "Tidak" (Sugiyono, 2012). Jawaban "Ya" mengidentifikasikan bahwa penerapan 10 area kontrol pada ISO 27001:2013 telah dilaksanakan, jawaban "Tidak" mengindikasikan penerapan ke-10 area kontrol pada ISO 27001:2013 tidak dilakukan dengan baik. Sistem penilaian pada kuesioner digunakan rumus deksriptif persentase (DP) sebagai berikut.

$$
\sum=\frac{N}{n} \times 100 \%
$$

Keterangan:

$\mathrm{N}=$ Skor diperoleh

$\mathrm{n}=$ Skor seharusnya

Berdasarkan rumus tersebut dapat ditafsirkan dengan kriteria penilaian sebagai berikut.

Tabel 3. Rentangan Kriteria Penafsiran

\begin{tabular}{ll}
\hline \multicolumn{1}{c}{ Interval (\%) } & \multicolumn{1}{c}{ Kriteria } \\
\hline $75,01-100,00$ & Sangat baik \\
$50,01-75,00$ & Baik \\
$25,01-50,00$ & Cukup baik \\
$1,00-25,00$ & Kurang baik \\
\hline
\end{tabular}

\section{HASIL DAN PEMBAHASAN}

$\mathrm{Bab}$ ini diketengahkan mengenai hasil penelitian yang telah dilakukan dilanjutkan pembahasan sebagai bentuk diskusi dari hasil temuan penelitian.

\section{Hasil Penelitian}

SIKAPEG merupakan sistem informasi yang dirancang untuk memberikan solusi dalam menangani berbagai hal terkait dengan kepegawaian mulai dari penyimpanan dan pemusatan data pegawai secara komputerisasi hingga menangani berbagai macam laporan kepegawaian di IVET. Berdasarkan hasil wawancara dengan Kepala Kepagawaian dan Kepala Unit TIK diperoleh gambaran sebagai berikut.

Tabel 4. Security Policies/Kebijakan Keamanan A.5. Security Policies

A.5.1. Information Security Policy/Kebijakan Keamanan Informasi

\section{Objektif:}

Mengarahkan manajemen dan dukungan keamanan informasi disesuaikan kebutuhan bisnis dan hukum yang relevan.

Kontrol:

1.Informasi mengenai dokumen kebijakan keamanan

2. Review tentang kebijakan keamaan informasi

Tabel di atas, kebijakan keamanan berguna untuk memberikan arahan manajemen dan dukungan pada keamanan informasi sesuai kebutuhan lembaga dan aturan di IVET. Kebijakan sudah berjalan cukup baik, karena telah tercatat pada aturan kepegawaian IVET 2017 sebagai dokumen kebijakan oleh Pimpinan IVET meski belum sesuai tuntutan ISO 27001:2013.

Tabel 5. Organisation of Information Securityl Organisasi Keamanan Informasi

\begin{tabular}{|c|c|}
\hline \multicolumn{2}{|r|}{ A.6. Organisation of Information Security } \\
\hline & 1. Internal Organization/Organisasi Internal \\
\hline \multicolumn{2}{|c|}{ Objektif: } \\
\hline \multicolumn{2}{|r|}{ Mengelola keamanan informasi dalam organisasi } \\
\hline \multicolumn{2}{|r|}{ Kontrol: } \\
\hline & $\begin{array}{l}\text { Komitmen manajemen terhadap keamanan } \\
\text { informasi }\end{array}$ \\
\hline & Informasi koordinasi keamanan \\
\hline & $\begin{array}{l}\text { Alokasi informasi dan taggung jawab } \\
\text { keamanan }\end{array}$ \\
\hline & $\begin{array}{l}\text { Proses otorisasi untuk fasiitas pengolahan } \\
\text { informasi }\end{array}$ \\
\hline & Perjanjian kerahasiaan \\
\hline & Kontak dengan otoritas \\
\hline & Kontak dengan kelompok minat khusus \\
\hline & Ulasan independent informasi keamanan \\
\hline
\end{tabular}


Organisasi keamanan informasi berfungsi mengelola keamanan informasi telah ada dan berjalan baik. Kontrol ini dilakukan oleh Unit TIK yang bertugas mengelola keamanan SIKAPEG. Selama ini keamanan informasi hanya menjadi tanggungjawab Unit TIK, ini yang menjadikan kelemahan. Penerapan aturan keamanan khusus SIKAPEG hanya disampaikan secara lisan dan belum terdokumentasikan/tertulis.

Tabel 6. Kebijakan Eksternal

\begin{tabular}{l}
\hline A.6.Organization of Information Security \\
\hline A.6.2. External Parties/Pihak External \\
\hline Objektif: \\
\hline Menjaga keamanan informasi dan pengolahan \\
informasi fasilitas organisasi yang diakses, diolah, \\
dikomunikasikan kepada, atau dikelola oleh pihak \\
ketiga. \\
\hline Kontrol: \\
\hline $\begin{array}{l}\text { Identifikasi risiko berhubungan dengan pihak } \\
\text { eksternal }\end{array}$ \\
\hline $\begin{array}{l}\text { Mengatasi keamanan ketika berhadapan } \\
\text { dengan pelanggan }\end{array}$ \\
\hline Mengatasi keamanan dalam perjanjian pihak \\
ketiga
\end{tabular}

Kontrol ini sudah dilakukan sangat baik, telah terdokumentasi/tertulis bahwa adanya pihak ketiga yang ikut dalam menjaga keamanan informasi. Bukti tertulis itu dilakukan melalui perjanjian (MoU) diawal dengan pihak pemberi sewa server/vendor.

Tabel 7. Human Resouurce Security (Keamanan SDM)

A.7. Human Resources Security/Keamanan Sumber Daya Manusia

\begin{tabular}{l} 
A.7.1. Priorto Employment/Sebelum Bekerja \\
Objektif: \\
Memastikan bahwa karyawan, kontraktor dan \\
pengguna pihak ketiga memahami tanggung \\
jawabnya, dan perannya pantas untuk \\
dipertimbangkan sebagai langkah untuk \\
mengurangi risiko pencurian, penipuan atau \\
penyalahgunaan fasilitas. \\
Kontrol: \\
\hline 1. Peran dan tanggung jawab \\
\hline 2. Screening \\
\hline
\end{tabular}

3. Syarat dan ketentuan dari employment

Terkait kepastian bahwa pegawai dan pengguna ketiga memahami tanggung jawab dan perannya serta mengurangi risiko pencurian, penipuan dan penyalahgunaan, kontrol ini telah dilakukan cukup baik. Setelah adanya sistem reward pegawai cukup antusias melakukan sidik jari meski masih ada pegawai yang hadir tidak tepat waktu. Sudah ada dokumen tentang peran dan tanggung jawab dari setiap unit/personal, tetapi job deskripsi serta rincian penggunaan dan manfaat dari fasilitas informasi pada setiap unit belum dirinci secara detail, sehinggga bila ada hambatan atau kerusakan data masih menjadi tanggung jawab lembaga, yaitu Kepala Unit TIK. Hal ini menjadikan setiap unit tidak memiliki tanggung jawab terhadap pencurian data dan hambatan dalam penggunaan informasi dari unit tersebut.

Tabel 8. Asset Management/Menejemen Aset A.8. Asset Management/Menejemen Aset

A.8.1. Responsibility for Assets

Objective:

Mencapai dan mempertahankan perlindungan aset organisasi

Kontrol:

1. Identifikasi aset secara jelas dan inventarisasi semua aset penting dibuat dan dipelihara

2. Aset yang terkait dengan fasilitas informasi, harus 'dimiliki' oleh bagian yang ditunjuk organisasi

3. Penggunaan informasi dan aset yang terikat dengan fasilitas informasi, harus diidentifikasi, didokumentasikan, dan diimplementasikan

Kontrol ini telah dilakukan cukup baik, inventarisasi aset hardware oleh Kepala Kepegawaian berkoordinasi dengan Kepala Rumah Tangga yang mencatat dan mendokumentasikan sehingga terbentuk daftar inventarisasi sebagai laporan. Inventarisasi aset software oleh Unit TIK, tetapi tidak dilakukan realtime/update. Penyajian daftar inventaris juga belum disajikan pada setiap ruang.

Tabel 9. Acces Control/Kontrol Akses A.9. Acces Control/Kontrol Akses 
Objektif:

Mengontrol akses ke informasi

Kontrols:

1. Kebijakan pengendalian akses

Kontrol ini sudah dilaksanakan baik. Kebijakan pengendalian hak akses telah dilakukan Kepala Unit TIK sebagai penanggung jawab organisasi yang mengelola keamanan SIKAPEG. Ka.Unit TIK dan Ka. Unit Kepegawaian diberikan kebijakan pengendalian hak akses dengan username dan password khusus sebagai admin untuk men-download data kehadiran pegawai yang digunakan sebagai bahan laporan kehadiran bulanan. Penggantian username dan password khusus dikembalikan ke masing-masing user, pegawai hanya bisa menggunakan maksimal 3 (tiga) sidik jari sebagai ID kehadiran. Mesin akan menolak sidik jari yang sama dengan ID berbeda, tetapi kebijakan kewenangan hak akses masih terkait dengan tugas dan kebutuhan lapangan serta belum terdokumentasi secara tertulis.

Tabel 10. Pysical and Environmental Security/ Keamanan Fisik dan Lingkungan

A.11. Physical and Environmental Security/ Keamanan Fisik dan Lingkungan

\section{Objektif:}

Mencegah akses tanpa ijin, kerusakan dan gangguan tempat dan informasi organisasi.

Kontrol:

1. Parameter keamanan fisik

2. Kontrol entri fisik

3. Mengamankan kantor, kamar dan fasilitas

4. Melindungi terhadap ancaman eksternal dan lingkungan

5. Bekerja di daerah aman

6. Akses publik, pengiriman dan pemuatan

Mencegah akses yang tidak sah terhadap kerusakan dan gangguan informasi organisasi telah dilakukan IVET dari keamanan secara fisik, kontrol fisik, dan pengamanan fasilitas yang dimiliki. Kontrol ini sudah dilakukan baik, mesin presensi sidik jari terletak di berbagai tempat yang mudah dijangkau. Ada 2 (dua) mesin kehadiran sidik jariyaitu di luar gedung A dan di dalam gedung $\mathrm{E}$, serta mesin presensi wajah yang berada di dalam gedung A. Meski mesin sidik jari yang terletak di depan gedung A mudah dijangkau, hanya peletakan mesin berada di luar gedung kurang aman dari ancaman pihak eksternal (kejahatan) karena memberikan peluang untuk sabotase alat dan bila terjadi hujan badai terancam basah dan rusak. Peletakkan mesin kehadiran wajah berada di tempat yang sering dilewati pegawai, sehingga pegawai harus berhati-hati bila tanpa sengaja wajah terekam mesin, karena pegawai akan terdata meninggalkan kantor meskipun masih jam kerja. Tempat penyimpanan data/CPU aman, karena berada dalam ruang dengan pemegang kunci terpusat di BAU. Sisi lain tidak tersedia (baca: belum) alat pemadam kebakaran/APAR, ini sangat berbahaya jika terjadi kebakaran. CCTV yang dimiliki IVET tidak berfungsi baik, CCTV banyak rusak dan penempatannya kurang strategis menjadikan tidak berfungsi sebagaimana mestinya. Tidak adanya CCTV yang mengarah pada mesin kehadiran sidik jari di sekitar gedung A (Rektoriat), gedung E, di sekitar TV monitor untuk penayangan laporan kehadiran secara online yang terpasang di lobby/costumer service dan ruang tempat penyimpanan data/CPU, sehingga bila ada tindak kriminal akan mengalami kesulitan untuk dilacak karena tidak adanya bukti rekaman peristiwa. Mesin kehadiran sidik jari, CPU, monitor pernah error/rusak pada waktu 3 (tiga) tahun terakhir, tetapi dapat diatasi dengan hardware cadangan. Pemeliharan software dan hardware serta aset pendukung lain dilakukan baik secara periodik, berkala maupun insidental. Insidental dilakukan ketika ada laporan dari setiap Kepala Unit Jurusan/Fakultas, secara periodik dilakukan pada setiap bulan, dan berkala dilakukan selama satu semester/enam bulan. Tindakan 
sudah dilakukan dengan baik, sebab setiap tindakan ada laporan dari penanggung jawab kepada pimpinan yang juga dibuktikan laporan setiap tindakan di kartu kontrol yang terpasang di ruang lengkap dengan barang yang dilakukan tindakan. Data kehadiran di-backup setiap bulan dan auto backup setiap hari. Hanya terdapat satu genset yang cukup digunakan di 1 (satu) gedung A/Rektorat). Software yang digunakan asli beralamat di http://kehadiran.ivet.ac.id. Sistem berjalan sesuai standar dan masih dapat digunakan dalam waktu panjang. Namun permasalahan dan kelemahan yang pernah muncul tidak terdokumentasi, sehingga tidak dapat digunakan sebagai bahan evaluasi ke depan.

Tabel 11. Operations Security/Keamanan Operasional

\begin{tabular}{l}
\hline A.12. Operations Security/Keamanan Operasional \\
\hline A.12.1.Operational Procedures\&Responsibilities \\
\hline Objektif: \\
\hline $\begin{array}{l}\text { Memastikan informasi kegiatan operasi dan } \\
\text { organisasi aman }\end{array}$ \\
\hline Kontrol: \\
\hline 1. Prosedur operasi yang didokumentasi \\
\hline 2. Merancang manajemen \\
\hline 3. Kapasitas manajemen \\
\hline 4. Pengembangan, pengujian. dan operasional \\
\hline
\end{tabular}

Kontrol ini sudah dilaksanakan cukup baik. Sudah ada prosedur operasi dalam penggunaan kehadiran sidik jari, tetapi belum ada prosedur operasi penggunaan SIKAPEG. Prosedur penyimpanan aset sudah ada dan dilakukan cukup baik, karena semua kegiatan yang akan dilakukan ke depan direncanakan terlebih dahulu secara tertulis diawali dengan rapat kebutuhan. Perancangan manajemen sudah ada dalam renstra (rencana dan strategi), tetapi pengembangannya belum dilakukan

Tabel 12. Communications Security/Keamanan Komunikasi

A.13. Communications Security/Keamanan Komunikasi
A.13.1.Network Security Management/Manajemen

Keamanan Jaringan

Objektif:

Memastikan perlindungan informasi dan fasilitas informasi pendukungnya.

Kontrol:

1. Kontrol jaringan

2. Pengamanan layanan jaringan

3. Segregasi dalam jaringan

Perlindungan informasi dan fasilitas informasi pendukung sudah dilakukan baik melalui kontrol jaringan dan pengamanan jaringan yang ketat. Kontrol ini sudah dilakukan baik, yaitu sebulan sekali tanpa ada kepastian waktu pelaksanaan. Manajemen keamanan jaringan menggunakan pergantian password yang dilakukan Kepala Unit TIK. Hal ini dilakukan antisipasi bila password dilacak oleh pihak lain berakibat pada pencurian dan perusakan data. Sudah ada pemisah/segregesi dalam jaringan. Dalam 1 (satu) tahun terakhir \pm 2 (dua) kali terjadi kerusakan jaringan. Wifi pernah tersambar petir \pm 4 (empat) kali pada saat musim hujan. Perbaikan jaringan terdokumentasi dalam foto dan email.

Tabel 13. System Acquistion, Development and Maintenance/Akuisisi Sistem, Pengembangan dan Pemeliharaan

A.14. System Acquisition, Development and Maintenance

A.14.1. Security Requirements of Information System /Aturan Sistem Keamanan Informasi

Objektif:

Memastikan bahwa keamanan informasi merupakan bagian integral dari sistem informasi, sebagai syarat dalam penyediaan layanan melalui jaringan publik.

Kontrol:

1. Analisis dan spesifikasi kebutuhan keamanan informasi

\begin{tabular}{cc}
\hline 2. & Mengamankan layanan jaringan publik \\
\hline 3. & Melindungi transaksi layanan aplikasi \\
\hline & Kontrol keamanan informasi sebagai
\end{tabular} bagian integral dari sistem informasi sudah dilakukan baik. Analisis kebutuhan 
keamanan informasi belum ada, tetapi spesifikasi kebutuhan keamanan informasi sudah ada. Tahun 2017 sistem pernah terkena virus sehingga menghambat kinerja sistem. Seiring perjalanan waktu dilakukan perbaikan, saat ini sudah ada bentuk pengaman dalam layanan jaringan publik dengan dilakukan pergantian password sesuai kebutuhan dan mantainance dengan cara mengontrol pada fasilitas jaringan. Upaya pencegahan dari serangan hacker dengan pemanfaatan firewall, setting file permission sudah sesuai kebutuhan dan prinsip keamanan, yaitu dilakukan backup data base dan data aplikasi rutin harian/mingguan/bulanan. Cara melindungi transaksi layanan dilakukan scanning atau pembersihan sistem pada setiap kegiatan dan awal pengoperasioan program. Kegiatan ini tidak terdokumentasi, karena telah dilakukan secara rutin, sehingga keseluruhan telah dilakukan baik, tetapi belum ada aturan mantainance aset software dan hardare.

Tabel 14. Information Security Incident Management/Manajemen Insiden Keamanan Informasi

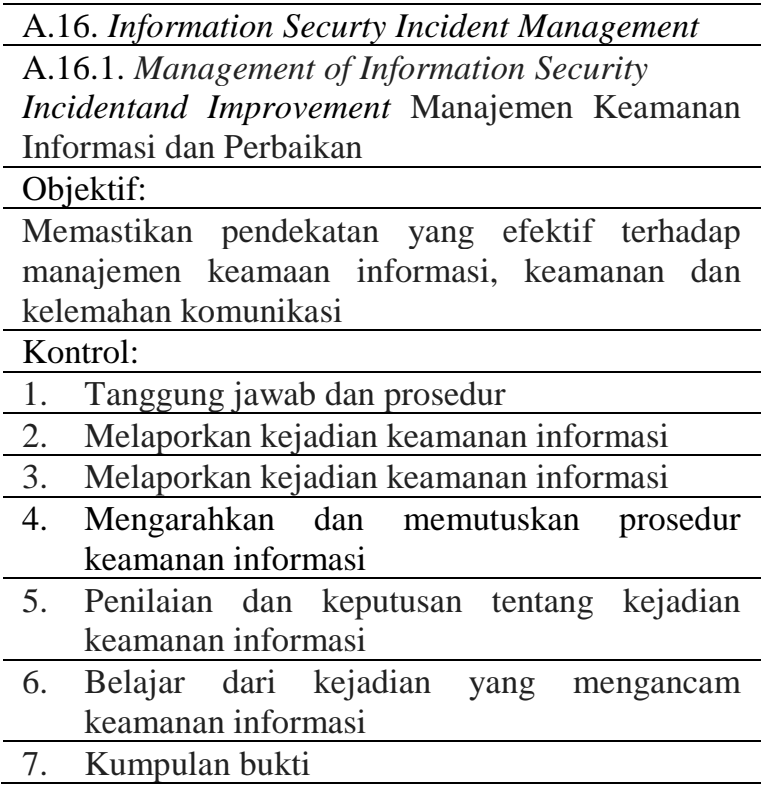

Kontrol ini dilakukan kurang baik, karena tidak ada tanggung jawab dan prosedur manajemen keamanan informasi.
Sampai saat ini belum ada pelaporan kejadian keamaan informasi dan bentuk pelaporan kelemahan. Pimpinan tidak pernah (baca: belum) memberikan arahan dan memutuskan prosedur keamanan informasi. Bila terjadi error/permasalahan pada SIKAPEG, misalnya: mesin kehadiran rusak, tidak bisa mendeteksi, SIKAPEG tidak bisa diakses, sistem hang, jaringan tidak stabil, admin melaporkan ke Kepala Unit TIK. Oleh teknisi dilakukan penanganan perbaikan, namun bila kerusakan membutuhkan perbaikan hingga mengganti alat, Ka.Unit TIK melakukan klasifikasi parameter kerusakan kemudian dilaporkan ke pimpinan dan diajukan dana untuk perbaikan/pergantian. Bentuk penilaian dan keputusan tentang kejadian bersifat keamanan informasi belum ada. Sudah ada bentuk pembelajaran dari kejadian yang mengancam keamanan informasi dengan cara perbaikan sesuai kebutuhan. Tidak ada bukti pelaporan kelemahan keamanan informasi terdokumen, maka tidak dapat digunakan sebagai bentuk evaluasi mendatang.

Berdasarkan analisis data hasil penelitian dari 10 area kontrol dapat direkap pada tabel berikut.

Tabel 15. Rekap Keseluruhan Tindakan Area Kontrol

\begin{tabular}{lcc}
\hline \multicolumn{1}{c}{ Kontrol } & $\begin{array}{c}\text { Rata- } \\
\text { Rata }\end{array}$ & Keterangan \\
\hline A.5. Security Policies & 33.33 & Cukup Baik \\
\hline $\begin{array}{l}\text { A.6. Organisation } \\
\text { Information Security }\end{array}$ & & \\
\hline $\begin{array}{l}\text { A.6.1. Internal } \\
\text { Organization }\end{array}$ & 58,33 & Baik \\
\hline A.6.2. External Parties & 100.00 & Sangat Baik \\
\hline $\begin{array}{l}\text { A.7. Human Resources } \\
\text { Security }\end{array}$ & 43.14 & Cukup Baik \\
\hline A.8. Asset Management & 50.00 & Cukup Baik \\
\hline A.9. Access Control & 72.22 & Baik \\
\hline $\begin{array}{l}\text { A.11. Physical and } \\
\text { Environmental Security }\end{array}$ & 58.06 & Baik \\
\hline A.12. Operations Security & 41.67 & Baik \\
\hline $\begin{array}{l}\text { A.13. Communications } \\
\text { Security }\end{array}$ & 66.67 & Baik \\
\hline A.14. System & & \\
\hline
\end{tabular}


Acquisition, Development

And Maintenance

A.16. Information Security $14.29 \quad$ Kurang Incident Management

Berdasarkan rekap tabel di atas dapat diperjelas dengan bentuk gambar grafik line berikut.

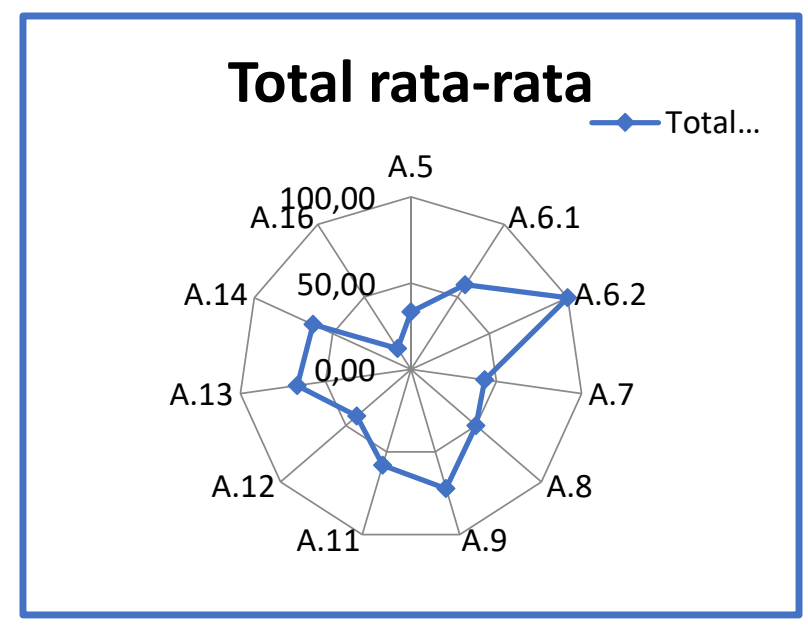

Gambar 1. Grafik line Rekap Keseluruhan Tindakan Area Kontrol

Rekapan tabel dan grafik di atas memberikan gambaran bahwa ancaman sistem informasi dalam SIKAPEG IVET meliputi: (1) pencurian data (data theft), yaitu adanya akses database dari orang yang tidak berwenang berakibat hilangnya hasil informasi, (2) penggunanan sistem secara ilegal, yaitu orang yang tidak berhak mengakses informasi untuk data seperti terjadinya kasus penipuan pihak eksternal dengan mengirimkan pesan singkat ke salah satu dosen IVET yang meminta pengiriman/ transfer uang untuk workshop ke pimpinan namun ternyata informasi tidak benar dan ternyata sebagai tindak penipuan, (3) penghancuran data secara ilegal, yaitu perusakan data/informasi dan membuat berhentinya sistem operasi komputer, (4) pemodifikasian ilegal, yaitu perubahan data dan perangkat lunak secara tidak disadari, karena terdapat perubahan data dan perangkat lunak yang disebabkan oleh program aplikasi yang merusak (malicious software) seperti virus, (5) sabotase mesin kehadiran sidik jari dan sistem, (6) kegagalan sistem, seperti pemadaman atau tegangan listrik (voltase) tidak stabil dapat membuat peralatan menjadi rusak dan terbakar, (7) human error, yaitu kesalahan pengoperasian sistem, (8) bencana alam, seperti: kebakaran, dan hujan badai.

\section{Diskusi}

Berdasarkan hasil wawancara dengan kepala unit TIK mengacu ke-10 area kontrol dan di-crosschek-kan dengan kepala kepegawaian dapat diketahui bahwa kebijakan keamanan SIKAPEG di IVET termasuk kriteria baik, hasil konsultasi dengan SMKI sebagai tolak ukur diperoleh kriteria mungkin. Kemungkinan ini bisa dijelaskan bahwa sistem memiliki peluang mengalami kerusakan antara 10-50\% akan terjadi pada periode waktu satu (1) tahun, jika dikaitkan dengan skala Likelihood termasuk kriteria ringan. Kriteria ini karena gangguan terhadap aplikasi/jaringan sistem tidak berfungsi > 1-4 jam selama jam kerja dan keluhan user disampaikan oleh sejumlah pengguna. Hal ini terjadi sebab IVET belum memiliki server besar memuat seluruh rangkaian sistem komputerisasi dan masih menyewa kepada vendor. Penyewaan ini didukung hasil wawancara dengan Kepala Unit TIK bahwa: "Sebenarnya SIKAPEG lebih aman diakses secara lokal karena tidak dibuka oleh publik, sehingga data daftar hadir tidak dibaca pihak lain, tetapi karena selama ini IVET tidak memiliki UPS data center dengan kapasitas data memadai, maka di-online-kan dengan menyewa server pada vendor (Wawancara Degha, 2017).

Organisasi keamanan informasi dengan berbagai indikator yang mengupasnya diperoleh kriteria baik, hail ini karena dalam pemanfaatan jaringan telah dilakukan kerjasama pihak Kepala Unit TIK dengan Kepala Kepegawaian dan juga dengan Kepala Rumah Tangga. Terkait 
dengan SDM juga telah ditempatkan person-person sesuai bidangnya. Misalnya kepala bagian/unit ditempatkan berdasarkan basis ijazah yang dimiliki/S1, bahkan untuk Kepala Unit TIK lulusan S2 bidang keahlian TIK.

Terkait dengan aset manajemen telah dilakukan inventarisasi cukup baik, dan dilakukan secara menyeluruh juga pelaporan kepada atasan. Bukti lain dapat diketahui, Kepala Rumah Tangga membuat daftar inventarisasi pada setiap ruang, meskipun beberapa ruang belum tarpasang. Terkait dengan kontrol akses, telah dilakukan dengan baik. Hal itu dilakukan perubahan password sesuai kebutuhan (periodik dan berkala), karena merupakan hak setiap user, maintanance meski waktu pelaksanaan tidak tetap. Pengalaman masa lalu menjadikan perubahan password dilakukan secara rutin. Hal itu didukung hasil wawancara dengan Dhega (2017): "Satu pegawai bisa memilik 4 (empat) sidik jari dari pegawai lain namun dengan ID satu pegawai, sehingga pegawai dengan mudah melakukan celah kecurangan, yaitu jika salah satu pegawai tidak masuk bisa diabsenkan oleh pegawai lain yang sidik jarinya telah terekam di mesin sebagai ID yang sama. Solusi dilakukan dengan reset data atau perekaman ulang data sidik jari maksimal 3 sidik jari setiap pegawai, selanjutnya adanya migrasi database dari server kantor ke server pusat (vendor). Tindakan penggantian password pada periode tertentu, perawatan dan pemeliharaan secara periodik dan berkala tidak hanya dilakukan pada pengamanan pada SIKAPEG saja, tetapi juga sekaligus sebagai antisipasi pencurian dan perusakan data terkait keamanan fisik, keamanan pengoperasian, keamanan jaringan, pengembangan ke depan, dan keamanan informasi serta perbaikan.

Kesuluruhan diskusi ditemukan bahwa ancaman keamanan SIKAPEG IVET termasuk kriteria medium. Hal ini didukung dari proses audit software menggunakan Tools Acunetix, yaitu web audit software yang berfungsi untuk men-scan kelemahan web. Hasil analisis termasuk level rentan berdasar Common Vulnerability Scoring System (CVSS) seperti tersaji pada tabel berikut.

Tabel 16. Qualitative Severety Rating Scale

\begin{tabular}{l|l}
\hline \multicolumn{1}{c|}{ Level/Rating } & \multicolumn{1}{c}{ CVSS Score } \\
\hline None & 0.0 \\
\hline Low & $0.1-3.0$ \\
\hline Medium & $4.0-6.9$ \\
\hline High & $7.0-8.9$ \\
\hline Critical & $9.0-10.0$ \\
\hline
\end{tabular}

Uraian di atas dapat dikonfirmasikan dengan pengukuran atau scanning pada SIKAPEG pada alamat http://kehadiran.ivet.ac.id. $\quad$ Pengukuran diperoleh hasil bahwa Acunetix mendeteksi 97 jenis total alerts found (total tanda ditemukan) terdiri dari 77 jenis yang bertipe medium, 13 low dan 7 Informational kategori Threat Level 2 (medium), seperti tersaji pada gambar berikut

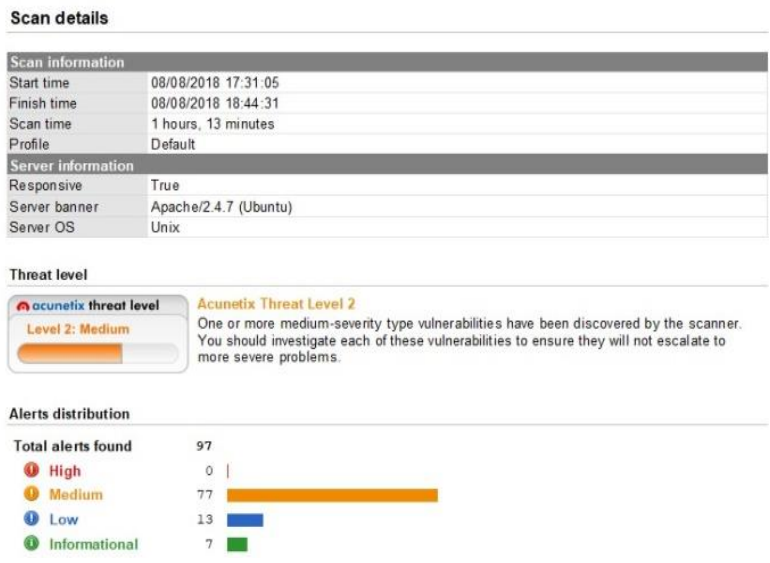

Gambar 2. Hasil Scanning SIKAPEG

Berikut disajikan repot hasil scanning SIKAPEG menggunakan Tools Acunetix: kategori medium dengan 77 jumlah jenis kerentanan, mulai dari skor 4,0 $-6,9$.

\section{Directorylisting/Daftar Direktori}

Alert details

Directory listing

Analisis Keaman

Type

Reported by module Scriphing (Directary__isfing gscipl

Description

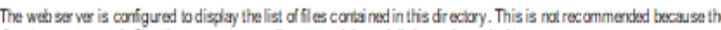

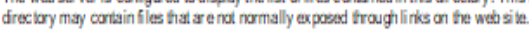


Gambar 3. Alert Details Directory Listing

Gambar di atas menjelaskan bahwa web server dikonfigurasi untuk menampilkan daftar file yang ada di directory. Ini tidak disarankan, karena directory mungkin berisi file yang tidak biasanya diekpos melalui link di website ini. Dampaknya pengguna dapat melihat semua file di directory yang mungkin terdapat informasi sensitif. Rekomendasi, untuk pastikan directory tidak memiliki informasi sensitif atau membatasi daftar directory dari konfigurasi web server.

\section{Error Message on Page}

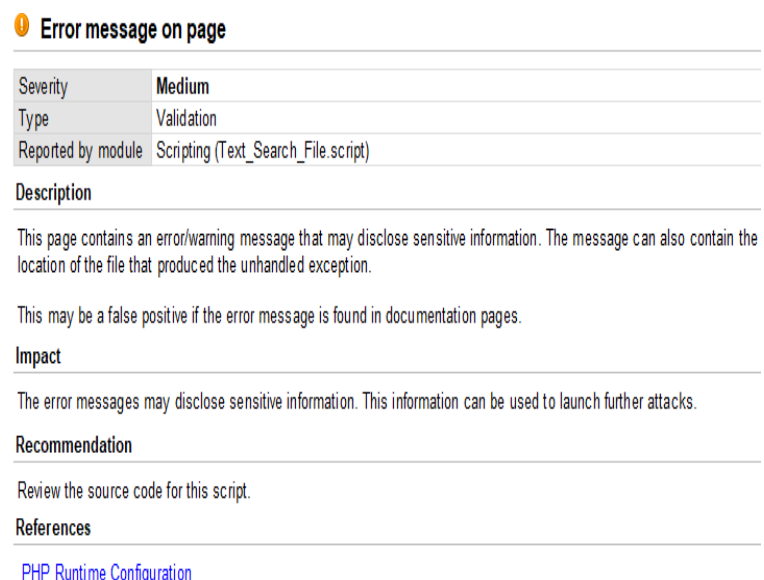

Gambar 4. Error Message on Page

Gambar diatas menjelaskan halaman ini berisikan pesan peringatan yang dapat membuka info sensitif, selain pesan juga menyajikan lokasi file tersebut. Dampaknya, error massage dapat membuka informasi sensitif, informasi dapat digunakan untuk menyerang. Rekomendasinya adalah sourcode perlu di review.

\section{HTML form Without CRFS Protection}

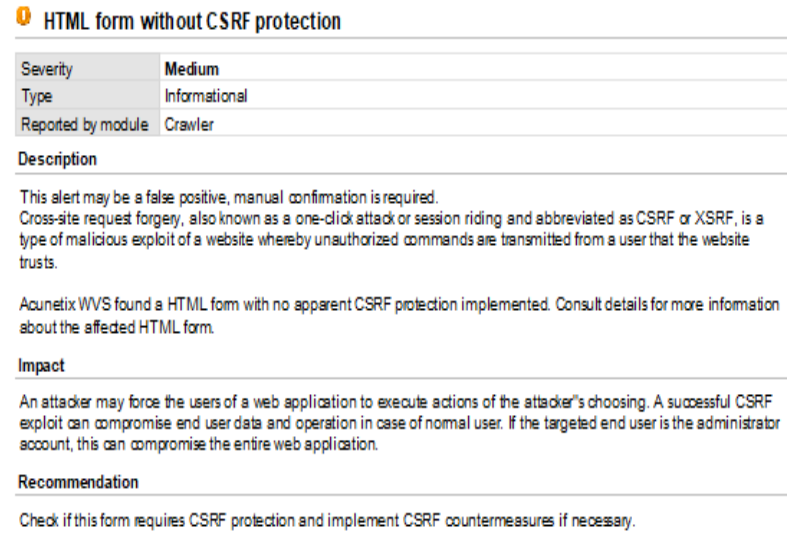

Gambar 5. HTML form Without CRFS Protection

Gambar di atas menjelaskan terdapat peringatan buruk, dibutuhkan konfirmasi manual. Cross-site dapat menimbulkan request palsu atau disebut one-click attack/serangan satu klik atau session ridding (cara untuk menyimpan informasi) dan CSRF or XSRF tipe serangan dari eksploit (kumpulan coding program untuk menyerang web) terhadap website, yaitu program yang ditransmisikan kepada user yang dipercayai oleh pengguna tersebut. Acunetix WVS menemukan HTML tidak memiliki perlindungan pada CSRF. Dampaknya, penyerang kemungkinan akan memaksa pengguna halaman web untuk memilih sesuatu yang diinginkan penyerang. Serangan CSRF exploit dikatakan berhasil bila dapat menguasai seluruh akun pengguna tanpa disadari. Jika targetnya administrator, maka seluruh halaman web menjadi dibawah kekuasaannya. Rekomendasi, chek apakah ada fitur memerlukan perlindungan CSRF dan implementasikan tindakan CSRF jika diperlukan.

\section{Slow HTTP Deniel of Service Attack}

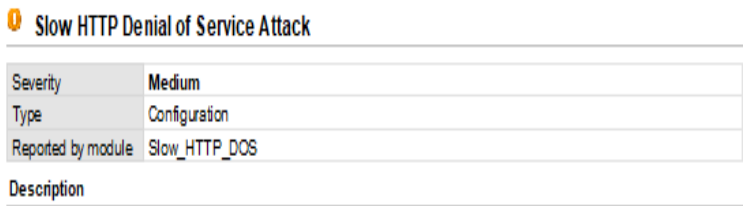

Analisis Keaman Your web sever is vunnerable to Slow HTTP DoS (Denial of Service) sttads

Slowloris and Slow HTTP POST DOS attads rely on the fad that the HTTP rotocol, by design, requires requests to be completely received by the enver before they ge rocossed lf an HTTP reques is not complete, or if the transfer rate is very low, the sever keeps its resources busy waiting for the rest of the data. If the senver keeps too many resouroes busy, this creates a denial of service. 
Gambar 6. Slow HTTP Deniel of Service Attack

Gambar di atas menjelaskan bahwa web server terlalu rentan ada serangan Slow HTTP DoS. Serangan Slow HTTP DoS tergantung fakta protokol HTTP. Secara desain membutuhkan permintaan agar diterima server sebelum diproses. Dampaknya, satu mesin dapat merusak mesin web server lain dengan bandwith minimal dan efek samping pada servis serta port yang tidak berkaitan. Rekomendasi, konsultasikan web referensi tentang informasi perlindungan web server melawan server tersebut.

\section{User Credentials are Sent in Clear Text}

\begin{tabular}{|c|c|}
\hline Severity & Medium \\
\hline Type & Configuration \\
\hline Repoted by module & Crawler \\
\hline Description & \\
\hline
\end{tabular}

User cedentials are tansmitted over an unenoypted channel. This infomation should always be tarsfered via an encypted channel (HTTPS) to avoid being interoepted by malidous uses.

Impact

A third party may be able to read the user credentials by intercepting an unencypted HTTP connection.

Recommendation

Becguse user credentials are considged sensitive information, should always be tranffered to the sever over an enoypted connection (HTTPS)

Gambar 7. User Credentials are Sent in Clear Text

Gambar di atas menjelaskan bahwa user credentials (surat mandat pengguna) dikirim melalui saluran yang tidak terenkripsi. Semua informasi harus selalu ditransfer melalui saluran terenkripsi (HTTPS) untuk menghindari agar tidak disadap pengguna yang jahat. Dampaknya, pihak ketiga mungkin dapat membaca user credentials dengan memotong koneksi HTTP yang tidak terenkripsi. Rekomendasi, karena user credentials dianggap sebagai informasi sensitif, informasi harus selalu ditransfer ke server melalui koneksi yang terenkripsi (HTTPS).

\section{Vulnerable Javascript Library}

Vulnerable Javascript library

\begin{tabular}{l|l}
\hline Severity & Medium \\
Type & Configuration \\
\hline Repoted by module & Scipting (Javasciipt_Librarie__Audit.sciipt) \\
\hline Description &
\end{tabular}

You are using a vulnerable Javascipt library. One or more vulnerabilities were reported for this vesion of the Javascipt library. Consult Attad details and Web References for more information about the affected librrary and the winerabilities that were repotted.

Impact

Consult Web References for more information.

Recommendation

Upgrade to the latest version.

Gambar 8. Vulnerable Javascript Library

Gambar di atas menjelaskan bahwa user menggunakan Java Script Library yang rentan. Konsultasikan detail serangan dan referensi web untuk informasi lebih lanjut tentang perpustakaan yang terkena dampak dan kerentanan yang dilaporkan. Dampaknya terjadi, konsultasikan referensi web untuk informasi lebih lanjut. Rekomendasi, tingkatkan ke versi terbaru.

\section{Web Application}

0 Web Application Firewall detected

\begin{tabular}{l|l}
\hline Severity & Medium \\
\hline Type & Configurstion \\
\hline Repoted by module & Scaipting (WAF_Detedion.scipt) \\
\hline
\end{tabular}

Description

This serves is protected by an IPS (Intrusion Prevention System), IDS (Intrusion Detection System) or an WAF (Web Application Firewall). Acunetix WS deteded this by sending various malicious payloads and detecting changes in the response wode, hesders and body.

Impact

You may receive incorrectíncomplete result when scanning a sever proteded by an IPSIDSNAF. Also, if the WAF detects a number of attads coming from the scannes, the IP address can be bloded atter a few attempts.

Recommendation

If possible, its recommended to scan an internal (development) version of the web spplication where the WAF is not sctive.

Gambar 9. Web Application

Gambar di atas menjelaskan bahwa server dilindungi oleh IPS (Intrusion 
Prevention System/Intruksi Sistem Pencegahan) atau WAF (Web Application Firewall). Acunetix WAF ini mampu mendeteksi dengan mengirimkan berbagai macam payloads (efek yang ditimbulkan serangan virus jahat yang dapat mendeteksi perubahan dalam kode respon, header dan body). Dampaknya, akan mendapatkan hasil yang tidak lengkap jika men-scan server yang dilindungi IPS, IDS/WAF. Jika WAF mendeteksi beberapa serangan dari scanner, IP address dapat di blok. Rekomendasi, jika memungkinkan men-scan versi internal dari aplikasi web, yaitu WAF tidak aktif. Berikut tabel rekap laporan celah keamanan yang ditemukan menggunakan Tolls Acunetix.

Tabel 17. Celah Keamanan dan Level Kerentanan

\begin{tabular}{|c|c|c|}
\hline No. & Celah Keamanan & $\begin{array}{l}\text { Severity } \\
\text { (Level) }\end{array}$ \\
\hline 1 & Directory listing & Medium \\
\hline 2 & Error message on page & Medium \\
\hline 3 & $\begin{array}{l}\text { HTML form without CRFS } \\
\text { protection }\end{array}$ & Medium \\
\hline 4 & $\begin{array}{l}\text { Slow HTTP Denialof Service } \\
\text { Attack }\end{array}$ & Medium \\
\hline 5 & $\begin{array}{l}\text { User credentials are sent in } \\
\text { clear text }\end{array}$ & Medium \\
\hline 6 & Vulnerable Java script library & Medium \\
\hline 7 & Web Application & Medium \\
\hline 8 & $\begin{array}{l}\text { Click jacking: X-Frame-Options } \\
\text { headre missing }\end{array}$ & Low \\
\hline 9 & $\begin{array}{l}\text { Cookie without Http Only flag } \\
\text { set }\end{array}$ & Low \\
\hline 10 & Options method is enabled & Low \\
\hline 11 & Possible relative path over write & Low \\
\hline 12 & Possible sensitive directories & Low \\
\hline 13 & Possible sensitive files & Low \\
\hline 14 & Possible virtual host found & Low \\
\hline 15 & Slow response time & Low \\
\hline 16 & Broken links & Informational \\
\hline 17 & Email address found & Informational \\
\hline 18 & $\begin{array}{l}\text { Error page web server version } \\
\text { diclosure }\end{array}$ & Informational \\
\hline 19 & $\begin{array}{l}\text { Password type input with auto- } \\
\text { complete enabled }\end{array}$ & Informational \\
\hline 20 & Possible user name or password & Informational \\
\hline
\end{tabular}

\section{diclosure}

Seluruh urain diatas menunjukkan hasil penelitian ini memberikan rekomendasi tentang mengurangi celah tindakan kriminal dari orang-orang yang tidak bertanggung jawab dan juga memberikan solusi terkait dengan perusakan data/informasi sebagai akibat kesalahan manusia atau humen error selain sebab-sebab dari gejala alam.

\section{PENUTUP}

Bab ini dibagi kedalam 2 (dua) sub bab, yaitu sub bab simpulan yang diperoleh dari pelaksanaan penelitian dan saran yang diharapkan dapat digunakan sebagai bahan rekomendasi.

\section{Simpulan}

Berdasar hasil analisis data, sistem keamanan Sistem Informasi Kehadiran Pegawai IVET belum memenuhi standar ISO 27001:2013, beberapa sudah dilaksanakan namun belum seluruhnya dilakukan dengan baik. Terjadinya ancaman termasuk kriteria mungkin terjadi, ini jika dilihat dari indikator kemungkinan terjadinya ancaman pada rentang antara 10$50 \%$ dalam waktu 1 (satu) tahun dan jika dikaitkan dengan skala Likelihood termasuk kriteria ringan, terutama gangguan terhadap aplikasi/jaringan. Kelemahan terletak tidak adanya tanggung jawab dan prosedur manajemen keamanan informasi. Bentuk ancaman dan kelemahaman itu: (1) pimpinan tidak pernah (baca: belum) memberikan arahan dan memutuskan prosedur keamanan informasi, (2) bukti pelaporan kelemahan keamanan informasi tidak terdokumentasi sehingga tidak bisa digunakan sebagai evaluasi ke depan, (3) kurangnya kesadaran pegawai dalam melakukan presensi sidik jari, secara bersama menjaga dan memelihara hardware pendukung. Solusinya adalah, 
dilakukan kontrol baik secara periodik maupun berkala, selain adanya perawatan dan pemeliharaan menyeluruh serta terdokumentasikan setiap kegiatan pada kontrol sistem.

\section{Saran}

Saran diperuntukkan bagi 3 (tiga) pihak, yaitu bagi pimpinan, bagi pegawai, dan peneliti mendatang.

Bagi pimpinan; sebaiknya pimpinan tegas dalam menetapkan aturan kepegawaian, baik penetapan reward maupun punishment, standar kerja, pembenahan sarana dan prasarana dengan SOP-nya, perawatan dan pemeliharaan barang dengan inventarisasi serta terdokumentasikan sesuai tuntutan ISO 27001: 2013, dan sebaiknya SIKAPEG hanya di-online-kan pada jaringan lokal IVET sehingga tidak memberikan peluang pihak yang tidak bertanggung jawab untuk menyabotase data.

Bagi pegawai; standar penggunaan sarana dan prasarana kerja serta keamanan telah ditetapkan pimpinan, namun masih ada beberapa pegawai yang belum memiliki komitmen melaksanakan tugas sesuai tanggung jawabnya. Disarankan kepada para pegawai IVET untuk melaksanakan hasil pembinaan dari pimpinan baik secara periodik maupun berkala, sehingga dalam memberikan layanan kepada publik sesuai standar ISO 27001:2013.

Bagi peneliti mendatang; penelitian masih terbatas dilakukan di IVET Semarang, disarankan untuk peneliti mendatang memodifikasi area kontrol dengan variabel atau faktor lain agar diperoleh hasil penelitian lebih bervariatif dan lebih serta ditemukannya teori atau konsep-konsep baru.

\section{DAFTAR PUSTAKA}

Aprian. R. Rizal S \& Sobri. M. 2015.

Perencanaan Sistem Manajemen

Keamanan Informasi Menggunakan

Standar ISO 27001:2013, Jurnal

Informatika Universitas Bina Darma

Palembang, digilib.binadarma.ac.id

Castro. Placida Rodal. 2016. Implementasi

Plan for an ISMS according to ISO/IEC

27001:2013, Universitat Obertade

Catalunya: Information Security

Management System.

Darmawan. Yohanes. 2017. Analisis Tata

Kelola Keamanan Laboraturium

Fakultas Teknologi Informasi

Universitas Kristen Satya Wacana

Menggunakan Standart ISO

27001:2013. Salatiga

ISACA. 2016. Comparisonof PCI DSS and

ISO/IEC 27001 Standards, ISACA

Journal Volume 1, 2016.

Kohar. Abdul \& Putro. Hanson Prihantoro.

2014. Ancaman Keamanan pada Sistem

Informasi Manajemen Rumah Sakit,

Seminar Nasional Informatika Medis

(SNIMed) V 2014, Magister Teknik

Informatika Fakultas Teknologi Industri

Universitas Islam Indonesia.

Kementerian Komunikasi dan Informatika

RI. 2017. Panduan Penerapan Sistem

Manajemen Keamanan Informasi

Berbasis Indeks Keamanan Informasi

(Indeks KAMI), Jakarta: Kementerian

Komunikasi dan Informatika Republik Indonesia

Kongo. Anggrini. 2016. Manajemen Risiko

Teknologi Informasi pada Perguruan

Tinggi Menggunakan Standar ISO/IEC

27001: 2013 (Studi Kasus: FTI UKSW Salatiga). Salatiga.

Laudon \& Laudon. 2015. Manajemen Information System: Managing the Digital Firm, New Jersey: Prentice-Hall 
Santos. AA Ternorio, Marwata, dan Sembiring. Irwan, 2014, "EMIS Information Systems Audit onthe TimorLeste Education Ministry with a COBIT4.1 Framework, International Journal of Computer Applications (0975-8887), Volume 89-No. 5, March 2014.

Sugiyono. 2012. Metode Penelitian Kuantitatif, Kualitatif, dan $R \& D$, Bandung: Alfabeta.
Tashakkori, Abbas dan Teddie, Charles. 2010. Mixed Methodology Mengkombinasikan Pendekatan Kualitiatif dan Kuantitatif. Yogyakarta: Pustaka Pelajar.

Wikipedia. 2018. CVSS / Common Vulnerability Scoring System (https://en.wikipedia.org/wiki/CVSS) diakses pada tanggal 18 Agustus 2018. 